\title{
УКРАЇНОМОВНІ НОМІНАЦІї В УРБАНІМІЦІ ХАРКОВА
}

Стаття висвітлює вплив мовної політики Росії, Радянського Союзу та Украӥни на урбаніміку Харкова. У статті авторка вперше виділила україномовні топоніми, щзо з'явилися у Харкові протягом XVII-XXI століть. Аналізуючи ситуацію з урбаністичними номінаціями вулично-дорожньої мережі, можна зробити висновок, що основна маса місиевих топонімів має двомовний характер, тобто і украйнською, і російською мовами вони звучать майже однаково. Причому є назви, шяо з'явились за часів Російської імперії або Радянського Союзу, які мають украӥнське походження $i$ російською мовою звучать так само, як і українською (Панасівка, Джерело, Квітуча) - тобто відбулася калька топоніму. У статті зазначається, щзо на сучасному етапі украйнізачії у Харкові поки щзо дотримуються двомовного паритету, проте вже зараз з'являються суто украйнські хороніми. Таким чином, можна констатувати, що державна мовна політика безпосередньо впливала на номінацію урбанонімів і в Російській імперії, $і$ в Радянському Союзі, і в сучасній Україні. Це особливо видно по періодах появи украӥномовних номінацій вулично-дорожньої мережі Харкова.

Ключові слова: Харків; державна політика; топоніміка; украӥнізачія; російська мова; українська мова; номінація.

The purpose of this article is to highlight the impact of the language policy of Russia, the Soviet Union, and Ukraine on the urbanism of Kharkov. The methodology is based on the principles of historicism, system, specificity, and science. Used such General historical methods as a retrospective, problem-based, micro-historical analysis. Scientific novelty. For the first time, the author identified Ukrainian-language toponyms that appeared in Kharkov during the XVII-XXI centuries. Analyzing the situation with urban categories of the road network, we can draw the following conclusions. The majority of local toponyms are bilingual. In other words, they sound almost the same in Ukrainian and Russian. Moreover, there are names that appeared during the Russian Empire or the Soviet Union, which have Ukrainian origin and sound the same in Russian as in Ukrainian (Panasovka, Dzherelo, Kvituchaya). That is, there was a tracing of the toponym. At the present stage of Ukrainization in Kharkov, so far, they adhere to bilingual parity. However, now there are purely Ukrainian burials. Thus, it can be stated that the state language policy directly influenced the nomination of urbanonyms in the Russian Empire, the Soviet Union, and modern Ukraine. This can be clearly seen in the periods of appearance of Ukrainian-language nominations of the Kharkov road network.

Key words: Kharkov; state policy; toponymy; Ukrainization; Russian language; Ukrainian language; nomination.

Постановка проблеми. Топоніміка дуже цікава i багатогранна наука. Вона вбирає у себе історичні події та процеси, що відбувалися чи відбуваються в державі. Через назви населених пунктів, вулиць, площ вона надає культурно-історичну інформацію про те, як населення ставиться до тих чи інших подій минулого й сучасного. Сьогодні в Україні відбувається процес українізації. Уряд намагається впровадити в усі сфери життя громадян українську мову. Тому цікаво звернутися до минулого, щоб побачити ретроспективу генези цього процесу у Харкові.

Метою даної статті $є$ висвітлення впливу мовної політики Росії, Радянського Союзу та України на урбаніміку визначено- го населеного пункту. Для демонстрації вживання україномовних слів були взяті різні типи топонімів у номінації вуличнодорожньої мережі досліджуваного міста.

До цього часу мовний аспект харківської топоніміки не розглядався у науковій літературі та журналістиці.

Аналіз актуальних досліджень. Для написання даної роботи були використані довідники, складені авторкою цієї статті у співавторстві із працівниками державної наукової бібліотеки ім. В.Г. Короленка i державного архіву Харківської області. Один із них - «Харьков: Справочник по названиям» - був опублікований у співавторстві у 2011 році [Дьякова, 2011]. Другий знаходиться в редакції [Дьякова, 2020]. У 
ньому містяться зміни, що відбулися в харківській урбаніміці протягом 2012-2019 pp.

Виклад основного матеріалу. Як, відомо, Харків був заснований черкасами у XVII столітті. Втікаючи з Речі Посполитої, вони селились на землях Дикого поля, що у цей час уже були під контролем Російської держави. Поруч із черкасами царський уряд розселяв своїх підданих.

У XVII-XVIII століттях Харків складався 3 фортеці (города) і підгородніх слобідок (тобто під горою, де стояв город). Слобідки розташовувалися за річками Лопань, Харків, Нетеч (старе русло річки Харків).

Переселяючись на нові місця, люди давали своїм поселенням найменування. Ці назви були пов'язані з ім'ям першопоселенця або з ремеслом, яким займалися мешканці. В український та російських мовах вони звучали майже однаково - 3 різницею лише в одну літеру: Іванівка/Ивановка, Гончарівка/Гончаровка, Журавлівка/Журавлёвка. Утім, серед цих номінацій є такі, що зберегли своє україномовне звучання до наших днів. Наприклад, це - Панасівка. Наприкінці XIX - у першій половині XX століття місцева адміністрація намагалося перекласти назву російською мовою Афанасьевка [Дьякова, 2011: 389, 407]. Але місцеві жителі не сприйняли переклад. I сьогодні харків'яни і українською, і російською мовами називають цю місцевість майже однаково - Панасівка/Панасовка. До речі, навіть не намагалися перекласти російською мовою назву однієї з перших вулиць Харкова - Чоботарську (у російському вигляді вона звучить як Чеботарская, але не Сапожная).

Ці невеличкі урбанімістичні рисочки свідчать про перебування в Харкові численного черкаського/українського населення.

Із часом Харків став русифікуватися. Це трапилося після отримання ним наприкінці XVIII століття статусу губернського центру, а також відкриття у XIX віці низки середніх і вищих навчальних закладів (зокрема, університету, ветеринарного і технологічного інститутів) та великої кількості промислових підприємств. Через це в місті з'явилося багато іноземців, що і призвело до переваги російської мови над українсь- кою.

У 1894 році Міська Дума прийняла рішення про увічнення пам'яті людей, що багато зробили для Харкова, ліквідації неблагозвучних та однойменних назв [Журнал... 1894]. Взагалі для XIX - початку XX століття характерними були антропонімічні (на честь людей), географічні, агіонімічні (на честь релігійних установ, свят) і теонімічні (власне ім'я божества) номінації. Майже однакове звучання у мовах топонімів не викликало негативної реакції.

У той же час завдяки відкриттю університету (1805 рік) саме Харків стає колискою українського національного відродження. На початку ХX століття це відбилося у появі таких урбанонімів, як: Гетьманська, Кобзарська, Козацька, Українська вулиці [Дьякова, 2011: 40, 118, 134, 324].

Довідники XIX - початку XX століть, де наводилися переліки дорожно-транспортної мережі міста, друкувалися російською мовою, тож чи вимовлялися ці назви українською мовою, сьогодні сказати важко [див., наприклад, Радомышльский 1910; Весь Харків 1930]. Отже, у Російській імперії вулично-дорожній мережі Харкова надавались номінації як російською, так i українською мовою.

Ситуація змінилась після приходу до влади більшовиків і встановлення радянської влади. У 1923 році на ХІІ з'їзді РКП(б) у Радянському Союзі був узятий курс на коренізацію, тобто підтримку національних мов і культур. В Україні цей процес отримав назву українізації. У даний період у Харкові - столиці України - відбувається спорудження нових великих підприємств, що тягнуло за собою масове житлове будівництво, а значить і збільшення вуличнодорожньої мережі. А ще у цей час відбувається приєднання приміських околиць до складу міста.

Під час українізації деяким хоронімам присвоювалися нові імена українською мовою. Причому і сьогодні у побуті вони звучать в україномовній інтерпретації навіть по-російські: вулиця Виробнича/Выробныча у селищі 2-й Комінтерн (Салтівка), вулиця і провулок Громадські/Громадские на Плеханівці (причому паралельно вони назива- 
лись Суспільна/Суспильная), провулок Джерело/Джерело на Москалівці.

Після згортання українізації і проведення русифікаторської політики, радянський уряд користувався українською мовою для найменування політичних урбанонімів. Це перш за все стосується термінів Жовтневий/Октябрьский та Радянський/Советский - у місті з'являються окремі топоніми 3 такими номінаціями як українською, так i російською мовами. Так, у Харкові у 1936 році на Павлівці з'явилась вулиця Жовтнева/Жовтневая, а у довіднику 1938 року відзначена вулиця Октябрьская (російською мовою) на Рашкіній Дачі. Паралельно із Радянськими/Радянскими (вулицею та в’їздом на Новоселівці) існували Радянські/Советские провулки у центрі міста.

Починаючи 3 1920-х років довідкові книги, де $є$ списки вулично-дорожньої мережі Харкова, друкуються паралельно російською та українською мовами. Причому відбувався відповідний переклад: одна із центральних площ міста російською мовою звучала Советской Украиньл, а українською - Радянської Украӥни, а, відповідно, вулиця Октябрьской Революции була Жовтневої Революичіi.

Окремо хотілося б відмітити термін Червоний/Красныци. У 1930-х роках багато хоронімів отримали назву із прикметником «червоний»: Червоношкільна набережна, вулиці Червоного Орача, Червоного студентства, Червоного льотчика, Червоноселищуна, Червонопрапорна тощо. Згодом харків'яни трансформували ці номінації. У деяких урбанонімах прикметник «червоний» «відпав» (вулиця Студентська), за деякими цей прикметник закріпився, створивши складні слова (Червоноселищуна), а за деякими закріпився прикметний «красный» (Красного Льотчика). Кардинальні зміни сталися 3 найменуванням вулиці Червоного Орача. Спочатку вона стала просто Орача, а згодом іiі перейменували на Пахаря. 3 одного боку, цей факт можна вважати русифікацією. Але, з іншого, якщо у російськомовному місті залишити назву вулиці Орача, то це викликало б шквал реготу i жартів. Адже слово «орач» дуже схоже на російське «орать» (в смысле громко кричать, вопить, браниться и т.д.). Тут можна ще згадати й російські вислови «орать на всю глотку» або «орать дурниной»...

До речі, один із адміністративних районів Харкова - Червонозаводський - довгий час паралельно йменувався російською мовою Краснозаводский. Але з 1967 року за районом в обох мовах остаточно закріпилася назва Червонозаводський/Червонозаводский.

Після приєднання у 1968 році селища Велика Данилівка у Харкові з'явилась вулиця Квітуча/Квитучая. Намагання піi назвати «Цветущей» зазнало невдачі. Мешканці Великої Данилівки на питання: «Где тут улица Цветущая?» дають негативну відповідь. I не тому, що вони не є прихильниками російської мови - просто звикли до україномовної назви Квітуча i російський переклад сприймають не одразу.

У повоєнний період (від середини 1940-х років) аж до проголошення незалежності України номінації вулично-дорожньої мережі відбувалися російською мовою 3 перекладом на українську. Тим паче, що в основному це були антропонімічні та хронімічні (на честь важливих подій - революційних 1917 року і воєнних 1941-1945 років) номінації.

Отже, у Радянському Союзі розпочата українізація дала декілька україномовних урбанонімів, але основна маса була двомовною.

Після проголошення незалежності України сталися зміни у мовній політиці, що відбилося і на найменуваннях географічних об'єктів, зокрема, хоронімів, агронімів тощо. Наприкінці 1990-х років уряд наказав перекласти усі топоніми українською мовою. Через це стався конфлікт із харків'янами: нові назви не співпадали із тими, що були указані в прописці у паспорті. Тоді було прийнято рішення про залишення деяких російських урбанонімів в написанні українською мовою. Так, у Харкові з'явилася вулиця Роднікова (хоча в українській мові правильно Джерельна).

Тепер при номінації вулично-дорожньої мережі міська адміністрація, міська Рада намагалися обирати такі назви, щоб не дуже різнилися в українській та російській мовах. Так, в Харкові з'явились вулиці Дубова/Дубовая, Кипарисова/Кипарисовая, 
Білої Акаціӥ/Белой Акции, Жовтої Рози/Желтой Poзы, Шовковичноӥ/Шелковичный, провулок Ірисовий/Ирисовый тощо. Натомість на мапі Харкова почали з'являтися суто українські найменування: провулки Бузковий/Бузковый (а не Сиреневый), Оксамитовий/Оксамытовый (а не Бархатный), Пролісковий/Пролисковый (а не Подснежниковый), Порічковий/Поричковый (а не Смородиновый) [Дьякова, 2020].

Отже, у незалежній Україні все більше вводяться україномовні назви географічних об'єктів.

Висновки. Аналізуючи ситуацію 3 урбаністичними номінаціями вулично-дорожньої мережі можна зробити наступні висновки. Основна маса місцевих топонімів має двомовний характер. Тобто і українсь- кою, і російською мовами вони звучать майже однаково. Причому $\epsilon$ назви, що 3'явились за часів Російської імперії або Радянського Союзу, які мають українське походження і російською мовою звучать так само, як і українською (Панасівка, Джерело, Квітуча). Тобто відбулася калька топоніму. На сучасному етапі українізації у Харкові поки що дотримуються двомовного паритету. Однак уже зараз з'являються суто українські хороніми.

Таким чином, можна констатувати, що державна мовна політика безпосередньо впливала на номінацію урбанонімів і у Російській імперіï, і у Радянському Союзі, і в сучасній Україні. Це особливо видно по періодам появи україномовних номінацій вулично-дорожньої мережі Харкова.

\section{ЛIТЕРАТУРА}

Весь Харків: адрес.-довідк. кн. на 1930 рік. (1930). Харків: Харкруп.

Дьякова Е. В., Дмитриева Е.Н., Харченко Н. М. Харьков: Справочник по названиям: 7000 улич площзадей, площчадей, скверов, районов... (2011). Харьков, «Издательство САГА».

Дьякова Е.В., Дмитриева Е.Н., Харченко Н.М. Справочник по топонимике Харькова: рукопись. (2020) Электронный вариант.

Журнал очередного собрания Харьковской Городской Думы № 11 Заседание 15 сентября 1894 года. (1894). Харьков. С. 312-333. п. 3. О переименовании улиц, изменении нумерации домов и напечатании списка домовладельцев.

Радомышльский Р. (1910) Адрес Харькова: адрес. и справ. книга. Харьков: типо-литогр. «Худож.труд».

\section{REFERENCES}

Ves' Kharkiv ades.-dovidk. kn na 1930 rik. (1930). [All of Kharkov: address and reference book for 1930]. Kharkiv: Kharkrup [in Ukrainian].

DyakovaH. V., Dmitrieva H. N., Kharchenko N.M. (2011). Kharkov: Spravochnik po nazvaniiam 7000 ulits, ploschadey, skverov, rayonov... [Kharkov: Directory of names: 7000 streets squares, squares, squares, districts...]. Kharkov: "Izdatelstvo SAGA». [in Russian].

DyakovaH. V., Dmitrieva H. N., Kharchenko N.M 2020). Spravochnik po toponimike Kharkova: rukopis'. [The reference place names of Kharkov: the manuZhurnal ocherednogo sobraniya Kharkovskoy Gorodskoy Dumy № 11 Zasedaniya 15 srntyabrya 1894 goda.p. 3. O hereimenovanii ulits, izmenenii numeratsii domov $i$ napechatanii spiska domovladellysev (1894). [Journal of the regular meeting of the Kharkov city Duma No. 11 Meeting on September 15, 1894. Item 3. The renaming of streets, renumbering of houses and the printing of the list of homeowners]. Kharkov. S. 312333 [in Russian].

Radomyshllskiy R. (1910).Adres Kharkova: ades. $i$ sprav. kniga [). Address of Kharkov: address. and help. Book] Kharkov: «Hudozh.trud». [in Russian]. 